ビタミンC長期多量負荷中止後の健常者の

血圧值に及活す影響

今木 雅英* 三好 保* 多田 敏子*

大木元 繁* 石本 寛子* 勢井 雅子*

\title{
Effect of Discontinuation of Vitamin C Large Loading on the Blood Pressure in Healthy Men
}

\section{Masahide IMAKI*, Tamotsu MIYOSHI*, Toshiko TADA*, Shigeru OOGIMOTO*, Hiroko ISHIMOTO* and Masako SEI*}

The effect of discontinuation of the vitamin $\mathrm{C}$ large loading on the blood pressure was examined. We administered vitamin $\mathrm{C}$ at dose of $1 \mathrm{~g}$ /day for 24 months and then usual diet for 24 months to five subjects. The results are follows.

1) Serum vitamin $C$ concentration was about $1.6 \mathrm{mg} / \mathrm{dl}$ in the vitamin $C$ loading period.

2) After discontinuation of vitamin $C$ large loading, the systolic pressure in three subjects decreased significantly $(p<0.05)$ in the usual diet.

3) After discontinuation of vitamin $\mathrm{C}$ large loading, the diastolic pressure in two subjects increased significantly $(\mathrm{p}<0.05)$ in the usual diet.

\section{I 緒 言}

ビタミンCは, Pauling ら（1976）が大量服用 によるガン患者の延命効果を報告して以来, 大量 服用の効用が多数報告されている。例えば，感冒 の予防, コレステロールの低下作用, 血圧低下作 用, 白内障の予防, 慢性リュウマチの症状軽減, 精神安定, 貧血の予防効果等 (萩野, 1971 ; 臼谷 ら，1971；三石，1977)挙げられている。しかし， 実際の効果について疑問のあるものも多い。しか しながら，最近，一般住民のいわゆる「健康ブー ム」から，むやみにビタミンCを大量服用する者 も多くなっている。従来の研究は, ビタミンCの 大量服用による積極的効用面からのアプローチが
数多くなされているが，長期大量服用した後，す なわち長期間ビタミンCが飽和状態であった状 態から, 急激に濃度が減少した場合, 人体の生理 的機能にどのように影響を与えるかと言うような 副作用的な検討は殆どされていない，そこで著者 らは，長期間多量服用した後の血圧値の変動につ いて観察したので報告する。

\section{II 実験方法}

1984年 9 月から1988年 8 月の連続した 48 月 間，5名の志願被験者に通常食及び通常食にビタ ミンC $1 \mathrm{~g}$ /日を負荷させ，血圧值の変化を測定し た。その詳細は次のとおりである（図 1).

\section{1. 被験者}

* 徳島大学医学部公衆衛生学講座

* Department of Public Health, School of Medicine The University of Tokushima 


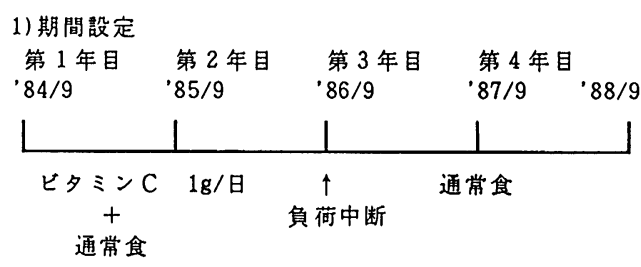

2) 被験者 : 健康な男性 5 名

3)血圧測定：毎月中旬に 1 回

図 1 実験計画

表 1 被験者の年齢及び体位（実験開始時）

\begin{tabular}{ccccc}
\hline 被験者 & 性 & $\begin{array}{c}\text { 年踰 } \\
(\text { 䁍 }\end{array}$ & $\begin{array}{c}\text { 身長 } \\
(\mathrm{cm})\end{array}$ & $\begin{array}{c}\text { 体重 } \\
(\mathrm{kg})\end{array}$ \\
\hline $\mathrm{A}$ & 男 & 55 & 164 & 69.0 \\
$\mathrm{~B}$ & 男 & 43 & 175 & 60.0 \\
$\mathrm{C}$ & 男 & 33 & 173 & 80.0 \\
$\mathrm{D}$ & 男 & 29 & 171 & 89.5 \\
$\mathrm{E}$ & 男 & 28 & 175 & 70.0 \\
\hline 平均値 & & 37.6 & 170.8 & 73.6 \\
標準偏差 & & 11.3 & 4.7 & 11.1 \\
\hline
\end{tabular}

被験者は, 高血圧性疾患, 心疾患, 糖尿病等の 慢性疾患の既往歴ない健康な男性 5 名である。い ずれの被験者も, 本研究の目的及び実施のための 詳細な内容を知らされたうえで，協力すると意向 表示した志願者である，その年龄，体位は，表 1 に示した。

2. 実験期間中の被験者の健康状態
1）一般的に良好な健康状態であった。

2）入院加療を要する疾病はなかった.

3） 3 日以上の連続した病気休暇はなかった。

4）高血圧性疾患に罹患しなかった。

5）心疾患，糖尿病等他の慢性疾患に罹患しな かった.

6）非契煙である。

7）常習的な飲酒はしなかった(いわゆる晚酌は しない).

8）職業上の配置転換はなく，ほぼ同じ業務を 行っていた.

9） $5 \mathrm{~kg}$ 以上の体重の増減はなかった.

10）降圧剂などの薬物を服用しなかった。

尚，被験者 $\mathrm{E} は ，$ 不慮の事故のため通常食期間 の途中で事験を中止した。

\section{3. 実験期間とビタミンC 負荷}

実験期間は，図 1 に示してあるように，2 年間 連続して，通常食にビタミン C $1 \mathrm{~g} /$ 日を負荷した。 実験 3,4 年目は通常食に戻した。ビタミン C $(\mathrm{L}$ アスコルビン酸, 粉末, 試薬特級, 和光純薬) 負 荷は朝食後 $0.5 \mathrm{~g}$, 夕食後 $0.5 \mathrm{~g}$ の粉末を摄取させ た。尚，通常食については，実験期間が長期にわ たるので被験者本人の従来の食生活といら意味で ある。被験者全員大きな生活環境の変化はなく, 一般的な食生活を実施していたと推測される。

4. 血圧測定及びビタミンC 測定

血圧測定は, 全期間同一の測定者, 測定器具 (手

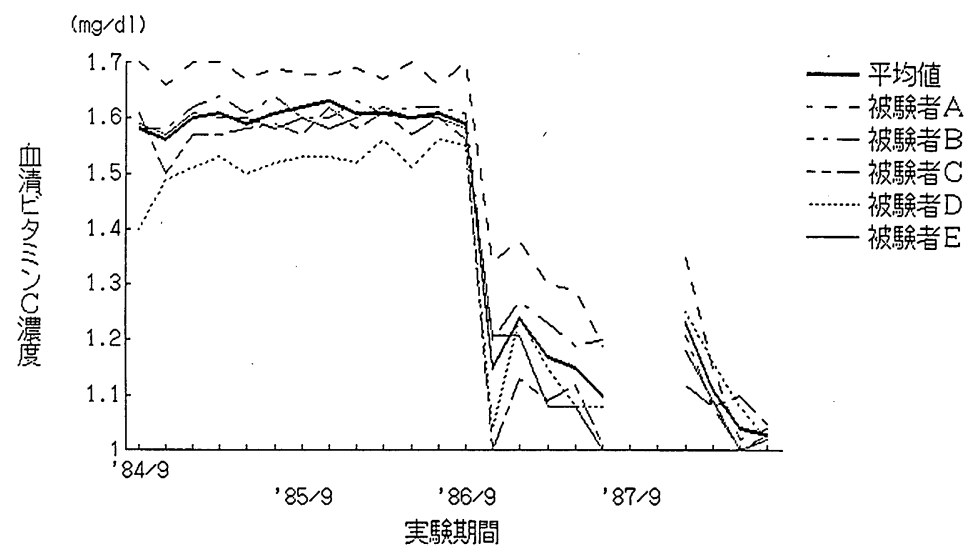

図 2 血清ビタミン $\mathrm{C}$ 濃度の変動 
動式水銀血圧計）を使用した，測定は，毎月中旬 に 1 回実施し, 朝 8 時, 飲食前に行った。血圧測 定後, 採血, 問診等の一般的検診も行った。

尚，血清ビタミン C 量は，Ayekaw（1972）の 方法により測定した，又，同一検体については， 少なくとも 2 回の測定を行い, その平均值とした。 血清ビタミン C 量はその日のうちに測定を終了
するようにした。

5. 被験者の在住地区

被験者の在住地域は徳島県徳島市であり, 平均 最高気温は $27.6^{\circ} \mathrm{C}$ ( 8 月), 平均最低気温 $12.5^{\circ} \mathrm{C}$ ( 2 月）である.
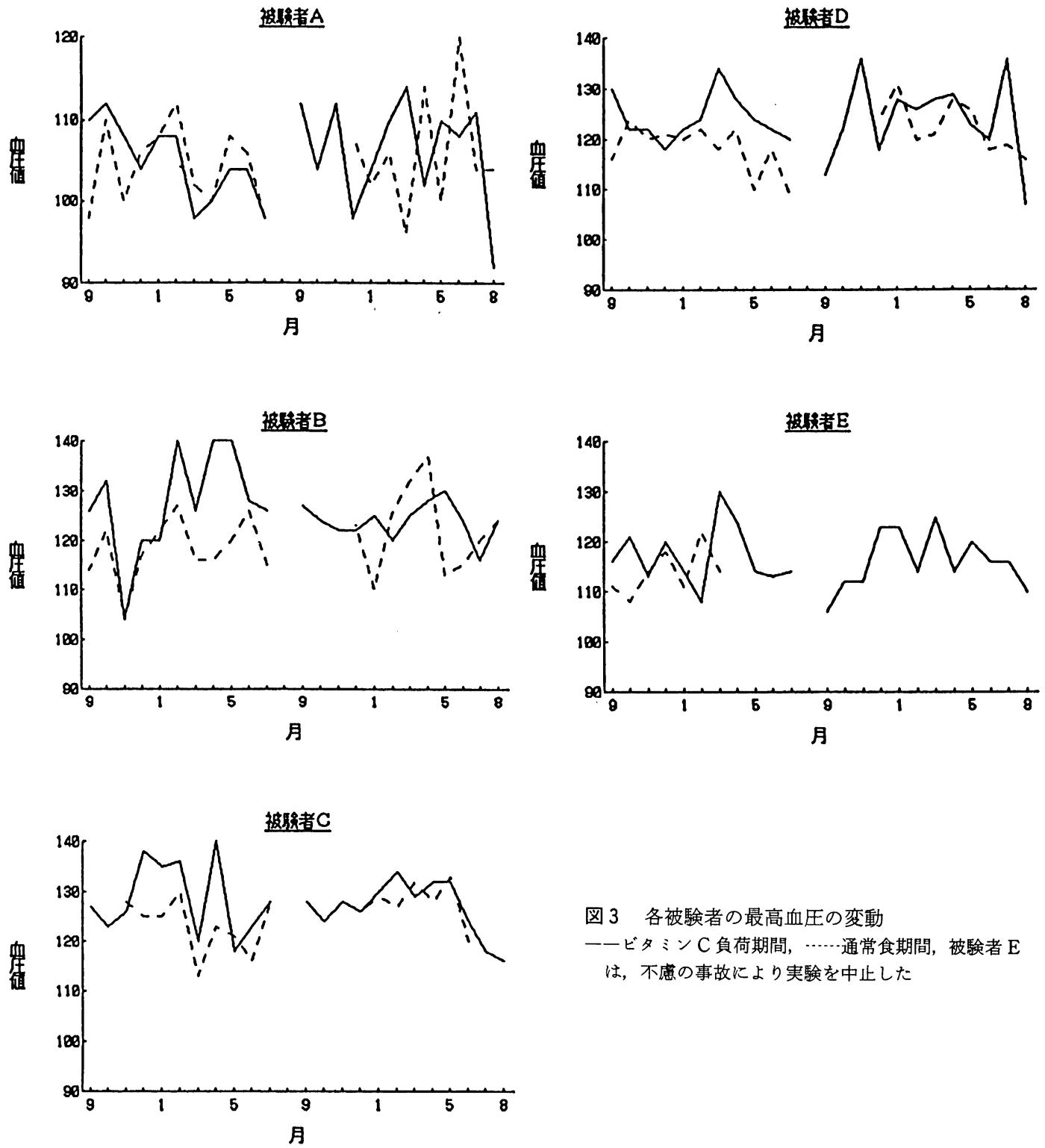

図3各被験者の最高血圧の変動

ーービタミン C 負荷期間, ……通常食期間, 被験者 $\mathrm{E}$

は，不虑の事故により実験を中止した 


\section{III 実験結果}

血清ビタミン $\mathrm{C}$ 濃度の变動を図 2 に示した。ビ タミン C 負荷期間中は, ほ注飽和濃度に達したと 考兄られ，変動は大きくなく平均 $1.6 \mathrm{mg} / \mathrm{dl}$ 付近 の值を示した。負荷を中止した後の通常食期にお いては，冬季に血清ビタミン C 濃度が上昇する傾
向が認められた。

図 3 は，各被験者のビタミン C 負荷期間中と通 常食期間中の最高血圧値の変動を示した．被験者

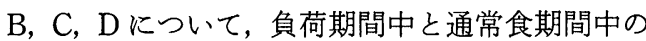
血圧値の平均值に統計学的に有意な差異を認め た。特に負荷中止後 1 年目は明らかに低値を示し ている (表 2 参照).
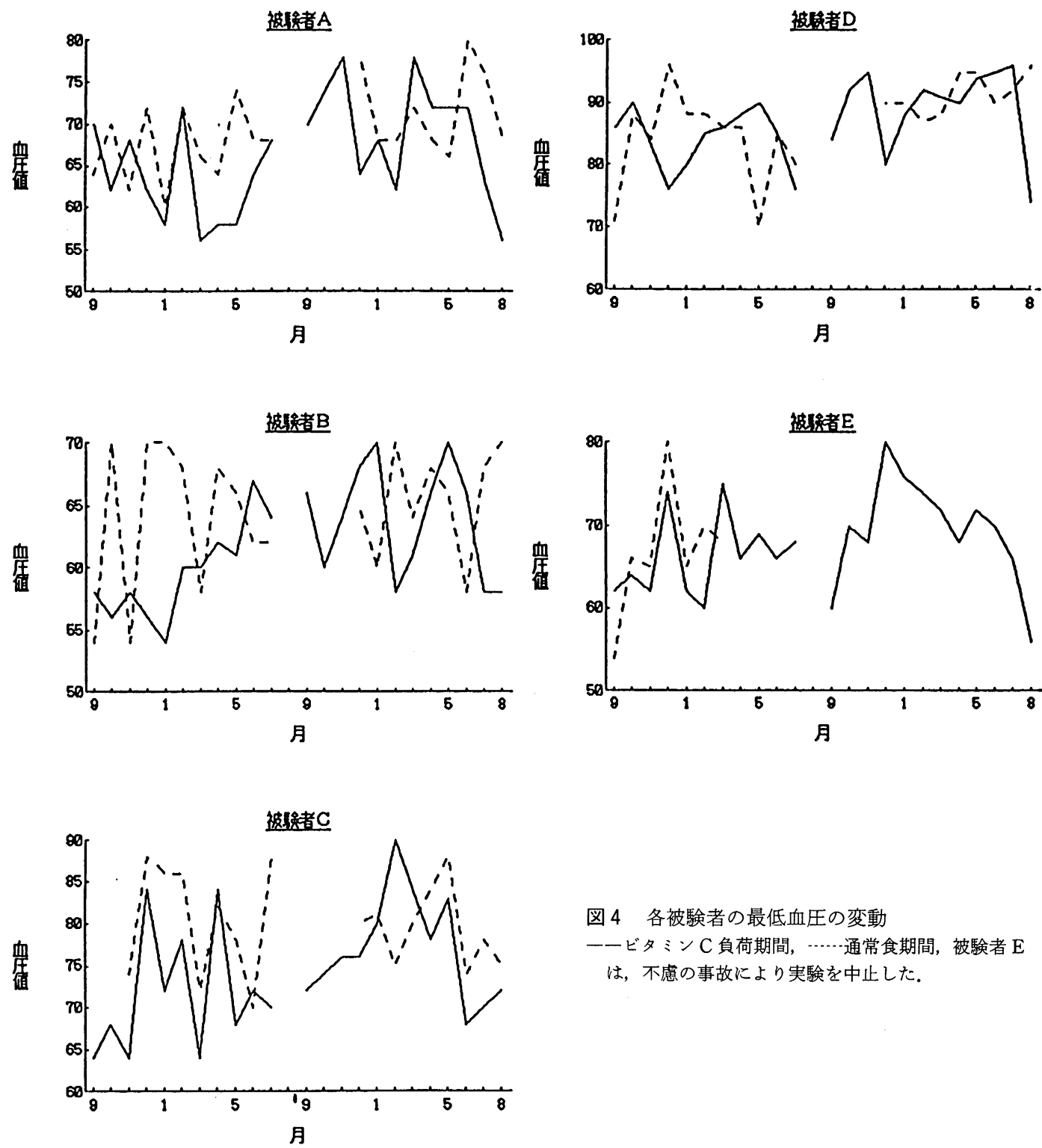

図4 各被験者の最低血圧の変動

- 一ビタミン C 負荷期間, ……通常食期間, 被験者 $\mathrm{E}$ は，不慮の事故により実験を中止した。 
表 2 最高血殴の変動

\begin{tabular}{ccc}
\hline 被験者 & $\begin{array}{c}\text { ビタミンC负荷期間 } \\
(24 \text { 月の平均值 })\end{array}$ & $\begin{array}{c}\text { 通常食期間 } \\
(24 \text { 平均値 })\end{array}$ \\
\hline $\mathrm{A}$ & $105.5 \pm 4.5$ & $105.9 \pm 5.3$ \\
$\mathrm{~B}$ & $127.0 \pm 5.1$ & $120.9 \pm 4.7^{*}$ \\
$\mathrm{C}$ & $129.0 \pm 6.2$ & $124.8 \pm 5.7^{*}$ \\
$\mathrm{D}$ & $125.0 \pm 5.2$ & $120.4 \pm 5.1^{*}$ \\
$\mathrm{E}$ & $118.0 \pm 5.4$ & $116.0 \pm 3.2$ \\
\hline 平均値 & $120.9 \pm 3.2$ & $117.1 \pm 3.3$ \\
\hline$*: \mathrm{p}<0.05$ & &
\end{tabular}

表 3 最低血圧の変動

\begin{tabular}{ccc}
\hline 被験者 & $\begin{array}{c}\text { ビタミンC負荷期間 } \\
(24 \text { 月の平均值 }\end{array}$ & $\begin{array}{c}\text { 通常食期間 } \\
(24 \text { の平均値 })\end{array}$ \\
\hline $\mathrm{A}$ & $65.4 \pm 5.5$ & $70.1 \pm 4.6^{*}$ \\
$\mathrm{~B}$ & $63.2 \pm 6.2$ & $65.9 \pm 5.8$ \\
$\mathrm{C}$ & $76.5 \pm 7.5$ & $80.5 \pm 6.0^{*}$ \\
$\mathrm{D}$ & $87.0 \pm 5.0$ & $87.8 \pm 5.3$ \\
$\mathrm{E}$ & $69.8 \pm 4.8$ & $70.7 \pm 5.3$ \\
\hline 平均値 & $73.2 \pm 5.8$ & $75.0 \pm 4.8$ \\
\hline$* \mathrm{p}<0.05$ & &
\end{tabular}

表 4 脈圧の変動

\begin{tabular}{ccc}
\hline 被験者 & $\begin{array}{c}\text { ビタミンC負荷期間 } \\
(24 \text { 月の平均値 })\end{array}$ & $\begin{array}{c}\text { 通常食期間 } \\
(24 \text { 月平均値 })\end{array}$ \\
\hline $\mathrm{A}$ & $39.6 \pm 6.2$ & $35.7 \pm 5.3^{*}$ \\
$\mathrm{~B}$ & $63.8 \pm 6.2$ & $55.2 \pm 6.3^{*}$ \\
$\mathrm{C}$ & $52.6 \pm 7.5$ & $44.2 \pm 5.2^{*}$ \\
$\mathrm{D}$ & $38.0 \pm 4.3$ & $39.8 \pm 1.5$ \\
$\mathrm{E}$ & $48.1 \pm 4.4$ & $45.5 \pm 5.7$ \\
\hline 平均値 & $48.4 \pm 4.3$ & $44.9 \pm 5.2$ \\
\hline${ }^{*}: \mathrm{p}<0.05$ & &
\end{tabular}

図 4 は, 各被験者のビタミン C 負荷期間中と通 常食期間中の最低血圧値を示した。被験者 $A, C$ に ついて, 負荷期間中と通常食期間中の血圧値の平 均値に統計的に有意な差異を認めた。又，各被験 者とも負荷中止後 1 年目は高值を示している. (表 3 参照)

表 4 は, 各被験者のビタミンC 負荷期間中と通 常食期間中の平均脈圧を示した。被験者 5 名中 3 名の負荷期間中と通常食期間中の脈圧值の平均値 に統計的に有意な差異を認めた。尚, 被験者 $\mathrm{E} に$
ついては，途中棄権したため実施した通常食期間 と対応するビタミン C 負荷期間のみ比較検討し ている.

\section{IV 考察}

ビタミンCは，Pauling ら（1976）が大量服用 によるガン患者の延命効果を報告して以来，大量 服用の効用が多数報告されている。インフルェン ザ, 肝炎等の感染症に対する人体の防御機能の立 進も報告されている。

そして，最近，一般住民の健康志向から多量の ビタミンを服用する者も多いそ蛙で，ビタミ ンC は水溶性ビタミンであるため, 余剰のビタ ンCは栱中及び尿中に排泄し, 過㮃摂取による副 作用はないとされている。しかしながら，長期大 量服用し, 長期の間血液中のビタミンC 濃度が飽 和状態にあり，その後突然服用を中止した場合， ぞのような影響を人体の生理的機能にもたらすか は興味あるものである，本報では，血圧值につい て長期間大量服用した後, 突然ビタミン C 服用を 中止させた後の血圧値の変動について観察した， 血圧值とビタミンCの関係については，村田ら （1984）の報告では契煙とは無関係に血浆ビタミン C 濃度と血圧とは有意な負の相関関係を認めてい る、又, 吉岡らも（1982）同様な傾向を報告して いる.つまり血清ビタミン C 濃度の高い者ほど, 血圧值が低レベルであると推察される，さらに小 堀（1960）は，ビタミンCの補給によって血圧値 が低下したと報告している。これらのビタミンC の血圧上昇抑制作用のメカニズムは十分に解明さ れていないが，家鬼に打ける実験的研究ではビタ ミンCはアドレナリン，ノルアドレナリン投与に よる血圧上昇を抑制し，又，アドレナリンに対す るビタミンCの昇圧抑制作用は，アトロピンによ り消失することが報告されており，つまりビタミ ンCは副交感神経に関与して，末梢の血管払張を もたらすものと考えられる。

本報に打いては, ビタミンC 負荷中止により最 高血圧は低下傾向を示し, 逆に最低血圧は上昇傾 向を認めた。つまり脈圧の低下が認められた。こ 
れらの結果から,ビタミンCの負荷中止により被 験者間の変動があるものの血圧值に影響を与えて いることを認めた。しかしながら本研究は, 長期 の実験のため他の変動要因の影響もあると考兄ら れ, この程度の変化ではビタミンC 負荷中止によ り血圧值に過度な影響を与えたと結論付けること は，難しいと言える。

\section{V 要 約}

最近，一般住民のいわゆる「健康ブーム」から， むやみにビタミンCを大量服用する者も多く なっている. 従来の研究は, ビタミンCの大量服 用による積極効用面からのアプローチが数多くな されているが, 長期大量服用した後, すなわち長 期間ビタミンCが飽和状態であった状態から, 急 激に濃度が減少した場合, 人体の生理的機能にど のように影響を与えるかと言うような副作用的な 検討は殆どされていない，そこで著者らは，長期 間多量服用した後の血圧値の変動について観察し たので報告した。その結果, ビタミンC負荷中止 により最高血圧は低下傾向を示し，逆に最低血圧 は上昇傾向を認めた。又, 脈圧の低下が認められ た、しかしながら，この結果程度の変化ではビタ
ミン C 負荷中止により血圧值に過度な影響を与 えたと結論付けることは，難しいと言える。

\section{文献}

Ayekyaw, (1972): A simple colorimetric methods for ascorbic acid determination in blood plasma, Clin. Chim. Acta, 40, 193-198

Careron, E. \& Pauling, L. (1976): Supplemental ascorbate in the supportive treatment of cancer prolongation of survival tives in terminal human cancer, Proc. National Acadmic of Science of U. S.A., 73, 3685-3689

萩野幸男 (1971)：気候ストレスに対するビタミンC の意義. 第 1 報。東北積雪地带住民に対するビタミ ン C 補給実験, 弘前医学, 22, 335-351

小堀義博 (1960)： アスコルビン酸の血圧作用に関す る実験的研究，弘前医学，12, 265-293

三石 㦑 (1977)：ビタミン C 健康法, 講談社 (東京) 村田 晃, 森永紀子, 加藤富民雄, 原田嘉文 (1984)： 定期健康診断に拈ける男子乫煙者の血嶈及び尿のビ タミンC 濃度, ビタミン, 58(2), 61-69

臼谷三郎, 中村 正, 菅原和夫 (1971): 気候ストレ スに対するビタミンC投与の意義。第 2 報。自衛隊 への投与と感冒, 呼吸器症候調査, 日本公衛誌, 18(6), 399-405

吉岡満城, 松下敏夫 (1982)：血清ビタミンC と血圧 について，日本医事新報，3033，29-31

（受稿 1990. 3. 11） 